\title{
How Does Banks' Total Factor Productivity Change During, Before and After Bank Consolidation Policy? Evidence from Nigeria
}

\author{
Iniwasikima Datonye Poloamina ${ }^{1}$, David Mautin $\mathrm{Oke}^{2}$, Olufunsho Abayomi Omobitan ${ }^{2}$, Ayoola Sunkanmi \\ Odubunmi $^{2} \&$ Salami Dada Kareem ${ }^{2}$ \\ ${ }^{1}$ Retired, Department of Economics, University of Ibadan, Nigeria \\ ${ }^{2}$ Department of Economics, Faculty of Social Sciences, Lagos State University, Nigeria \\ Correspondence: David Mautin Oke, Department of Economics, Faculty of Social Sciences, Lagos State \\ University, Ojo, Lagos, Nigeria. Tel: 234-803-863-0169 E-mail: okdam76@yahoo.com or \\ david.oke@lasu.edu.ng
}

Received: October 9, 2013

Accepted: June 30, 2014

Online Published: August 25, 2014

doi:10.5539/ijef.v6n9p221

URL: http://dx.doi.org/10.5539/ijef.v6n9p221

\begin{abstract}
The question about whether consolidation policy can raise bank's productivity is an interesting subject of discourse in monetary theory, though not too common. This present paper applied the Malmquist Data Envelopment Analysis to examine the total factor productivity changes (TFPC) of fifteen major deposit money banks in Nigeria over the 2004/2005 bank consolidation period, three years before and after. The results showed a similar productivity change in the pre- and bank consolidation era but revealed a slight reduction in the productivity thereafter. What constituted the major source of productivity growth in the banking industry was technological progress. However, there was no significant difference in the productivity change of the domestic and foreign banks, whose majority shares were held by expatriates.
\end{abstract}

Keywords: total factor productivity change, bank consolidation, malmquist data, envelopment analysis, Nigeria

\section{Introduction}

The Nigerian monetary sector has since 2000 experienced one banking reform to another. Prominent in her 2004/2005 banking sector reforms was capital consolidation of the banks which involved 1150 per cent increase in the minimum capital base of the deposit money banks (DMBs) from \$2 billion in July 2004 to 25 billion in December 2005. This was meant to strengthen the capacity of the banks to perform their intermediation roles with reasonable stability and efficiency. This unprecedentedly large capital base of the banks, among other issues, raised theoretical and practical questions about their capability of optimally deploying the funds to support productive activities and facilitate productivity change in their operations.

Productivity itself is a ratio of output to input and is essentially a level concept, one of the measures of performance of firms at a given point in time. Its changes popularly known as productivity change or changing productivity refers to movements in productivity performance of a firm or an industry or a government or any other entity over time. This concept is handy for corporate decision and policy making. Such decision is more economically sensible when considering cost productivity change involving the extent of change in cost of operation due to combination of change in best practice cost functions and change in inefficiency over time (See Rao, 2002).

Prior to 2004/2005 consolidation period in Nigeria, her commercial banks grew numerically from 14 banks (273 branches) in 1970 to 89 banks (3492 branches- 2765 urban branches, 722 rural and 5 foreign branches) in 2004.In addition, her merchant banks increased from only 1 in 1970 to 38 in 2000 with 113 branches (Central Bank of Nigeria, 2006). As part of the reforms in her banking sector in 2000, the Universal Banking policy was implemented which led to demise of the merchant banks until the repeal of the policy in December 2010. Many of the merchant banks applied for conversion into commercial banks in 2000 while others went out of business. The Universal banking policy which gave birth to the term "deposit money banks" in Nigeria was meant to ensure efficient delivery of financial services at reduced costs, and also improve bank risk-return profile via diversification effects (Note 1). Interestingly, as an early review, the post 2004/2005 bank consolidation did record more growth in branch network both locally and abroad. The number of domestic branches increased 
from 3492 in 2004 to 4085 in July 2007 with the highest concentration in Lagos (1314); followed by Abuja (225) and Rivers (205). Also, the number of foreign branches rose from 5 in 2004 to 13 in 2007 with the largest number in Ghana(4); followed by 2 branches each in Benin Republic, Gambia, UnitedKingdom and USA and 1 branch in Sierra Leone (Central Bank of Nigeria, 2006).

Therefore, the hypotheses the study sought to test include: (1) bank productivity growth in post consolidation and consolidation phases is more than that in pre-consolidation phase; (2) productivity of foreign banks outgrows that of domestic banks; and (3) technological progress constitutes a major propeller of total factor productivity growth in the Nigerian banking industry.

Following the introduction is section two which reviews the literature. Section three is on the methodology, data description and specification issues. In part four, the results of the empirical analysis and its interpretation are presented while the concluding remarks are made in the last section.

\section{Literature Review}

The Malmquist Index as a measurement of productivity change in banking industry was introduced by Berg, Forsund and Jansen (1992). Their study was on the productivity change of the Norwegian banking industry during the deregulation period, 1980-1989. The results obtained indicated that deregulation led to a more competitive environment. Also, the productivity growth was faster for larger banks, due to the increased antagonism they faced. This suggests that antagonism can yield favourable outcome in terms of productivity gain.Adopting the Malmquist DEA, Lee, Worthington and Leong (2008) in a similar analysis found some levels of total productivity growth associated with deregulation and scale efficiency improvement largely from merger amongst the local banks in Singapore. In United States, Bauer, Berger and Humphrey (1993) used a panel data set of 683 banks in the country with over $\$ 100$ million in assets to estimate total factor cost productivity growth for the best- practice banks during 1977-1988. Over the period, their estimates ranged from an average annual growth rate of $-2.28 \%$ to $0.16 \%$. According to them, the poor productivity growth was due to higher costs of funding owing to high market rates, elimination of deposit rate ceilings, and increased competition from non-bank financial intermediaries, which increased demand for funds and reduced the supply of deposits. Hence the banks increased the number of branches over the 1980s, in addition to paying higher deposit rates and providing the ATM innovation. The increase in deposit interest rates, non-bank competition, and better convenience all made consumers of bank services better off, but because quality of service is difficult to account for in the estimation, the higher quality showed up as a decrease in productivity- a paradox. Humphrey (1993) used the same data set to examine the effect of shifts in cost function on costs from 1977-1988. Measures were derived in three ways: from a simple time trend; a time-specific index; and annual shifts in cross-section cost functions. All the three methods yielded similar estimates, with shifts in the cost function implying cost increases averaging $0.8 \%$ to $1.4 \%$ per year, and small banks (with assets of \$100-\$200 million) experiencing larger increases on average than large banks. Humphrey attributed the decline in cost productivity to deregulation of deposit rates. In support of this hypothesis, he found that in the pre-deregulation period (1977-1980) productivity increased, while during deregulation (1981-1982), productivity declined substantially, and in the post deregulation period (1983-1988), it showed a little change.

In the study by Schure, Wagenvoort and O'Brien (2004) on the productivity of the European banking sector for the period 1993-1997, the Italian and the Spanish banks were found to be the least efficient. On the other hand, Casu, Girardone and Molyneux (2004) found that Italian banks had an 8.9\% productivity increase; Spanish banks had a 9.5\% increase, while German, French and English banks had 1.8\%, 0.6\% and 0.1\% productivity increase, respectively over the period 1994-2000. They alluded the main reason for such improvement in productivity of the Italian and Spanish banks to the cost reduction that these institutions managed to achieve.

Applying the DEA, Fernandez, Gascon and Gonzalez (2002) found that commercial bank productivity across the world had grown significantly (19.6\%) from 1989 to 1998. This outcome was principally due to relative efficiency improvement, with technological progress having a very moderate effect. Their study was on different geographical areas (North America, Japan and Europe) involving 142 financial intermediaries from eighteen countries over the period 1989-1998. The European banks were those from Austria, Belgium, Denmark, Finland, Germany, Ireland, Italy, Luxemburg, Norway, Portugal, Spain, Sweden, Switzerland and the United Kingdom. The three preferred outputs were total investments, total loans, non-interest income plus other operating income. In parallel, the four input variables were property, salaries, other operating expenses and total deposits. All these values were expressed in billions of US dollars. Additionally, Sufian and Majid (2007) adopted the Malmquist DEA in a similar investigation and found that in the productivity change components, pure technical efficiency is more related to overall efficiency than scale efficiency in Malaysia. 


\section{Methodology and Data}

There are several approaches for measuring total factor productivity ranging from Hicks-Moorsteen approach, Malmquist productivity index, profitability ratio to component-based approach. Thick Frontier Approach, Stochastic Frontier Approach, Malmquist Index and Malmquist Data Envelopment Approach (DEA) are popular methods in the literature that have been used to examine productivity change of banks. While the first two are stochastic or econometric methods, the last two are linear programming approaches. The choice of method should be dependent on the purpose of measuring productivity levels and change (see Coelli, Rao, O'Donnel,\&Battese, 2005). The nature of data should also determine the methodology adopted. We note that small sample data can be analyzed using the linear programming methods and are more convenient to use.

This paper uses the Malmquist DEA and the preferred inputs are deposits, labour and fixed assets while the outputs are performing loans and advances, short and long term investments and liquid assets (see Oke, 2011). These data were obtained from annual audited financial reports of fifteen deposit money banksout of the twenty five banks operating in the country after the 18 months (July, 2004-December, 2005 ) bank consolidation in Nigeria (Note 2). These sampled banks shared above 75 percent of the industry assets over the period under investigation (Note 3 ).

Drawing from Coelli et al. (2005), six models are specified in equation (1) to (6) (see the appendix) in which total factor productivity (TFP) change is decomposed into four components. First, based on Constant Returns to Scale (CRS) technology, TFP change is broken down into two: technical efficiency change in equations (1) and (2), technological change in equations (3) and (4). Using Variable Returns to Scale (VRS) technology, technical efficiency change helps us obtain scale efficiency change (ratio of CRS technical efficiency change to VRS technical efficiency change) in equation (5) and pure efficiency change in equation (6). Since Malmquist DEA requires a balanced panel data for estimation, a pooled data of 120 samples over the period, 2001-2008 were employed. Linear Programming duality principle in which minimization problem can be converted to maximization problem was used. In line with Coelli et al. (2005), we assumed that there are $\mathbf{N}$ inputsand $\mathbf{M}$ outputs for each of $\mathbf{I}$ bank. For the i-th bank, these are represented by the column vector $\mathrm{x}_{\mathrm{i}}$ and $\mathrm{q}_{\mathrm{i}}$, respectively. The $\mathbf{N} \times \mathbf{I}$ input matrix, $\mathbf{X}$, and the $\mathbf{M} \times \mathbf{I}$ output matrix, $\mathbf{Q}$, represent the data for all $\mathbf{I}$ banks. Note that $\varnothing$ is a scalar and $\lambda$ is a $I \times 1$ vector of constants in equation (1) to (4). The value of $\varnothing$ obtained is the productivity/efficiency score for the i-th bank. The value of Øis 1 if there is no productivity/ efficiency change; less than 1 if the productivity/efficiency change declines; and greater than 1 if the productivity/ efficiency change increases or grows (see Coelli et al., 2005). The I1 in equations (5) and (6) is an I $\times 1$ vector of ones. This approach forms a convex hull of intersecting facet that envelopes the data points more tightly than the CRS conical hull and thus provides technical efficiency scores that are greater than or equal to those obtainable using the CRS model. The convexity constraint (I1 $\lambda=1$ ) essentially ensures that an unproductive/inefficient bank is only "gauged" against banks of similar size. This convexity restriction is not imposed in CRS case. In CRS technology, a bank may be benchmarked against banks that are substantially larger (smaller) than it. In this instance, the $\lambda$-weights sum to a value less than (greater than) one.

The statistical significance of average measured productivity change in the pre-consolidation, consolidation and post-consolidation periods is tested using the Friedman's analysis of variance (ANOVA) test. This approach is a non-parametric ANOVA which was propounded by Friedman in 1937 (Field, 2009). Unlike parametric ANOVA, its adoption becomes necessary because of our few data points leading to small degree of freedom. While parametric ANOVA uses data assumed to have normal distribution, the Friedman's ANOVA ranks the data.Once the sum of ranks has been calculated for each group, the test statistic, $\mathrm{F}_{\mathrm{r}}$ is computed as:

$$
\left[\frac{12}{N k(k+1)} \sum_{i=1}^{k} R_{i}^{2}\right]-3 N(k+1)
$$

Where $\mathrm{R}_{\mathrm{i}} \mathrm{is}$ the sum of ranks of each group, $\mathrm{N}$ is the total sample size and $\mathrm{k}$ is the number of groups or conditions (in this case 3 ). When $\mathrm{N}$ is large, bigger than about 10, the test statistic has a chi-square distribution with the degree of freedom being k-1 (Field, 2009).

\section{Results and Discussion}

Table 1 presents the Malmquist Index results of measured average productivity change of the Nigerian banks. The technical efficiency change in the banking industry for the period 2001-2008 was 0.979 while the technological change amounted to 1.049 . The value of the pure technical efficiency change, scale efficiency change and total factor productivity change were $0.992,0.987$ and 1.027 respectively. Similar to the finding of Sufian and Majid (2007) pure technical efficiency change contributed more to total productivity change than 
scale efficiency change, although the difference was a slight one. Contrary to Fernandez et al. (2002), technological progress largely accounted for total factor productivity change and not moderately. This result also showed that only technological change was consistent over the period except in the wake of the consolidation when there was a technological decline. Therefore, Nigerian banks have continued to leverage on technological progress in raising their productivity.

Table 1. Malmquist index summary of measured average productivity change of the deposit money banks (20022008) (Note 4)

\begin{tabular}{cccccc}
\hline Year & $\begin{array}{c}\text { Technical } \\
\text { Efficiency Change }\end{array}$ & Technological Change & $\begin{array}{c}\text { Pure Technical } \\
\text { Efficiency Change }\end{array}$ & $\begin{array}{c}\text { Scale Efficiency } \\
\text { Change }\end{array}$ & $\begin{array}{c}\text { Total Factor } \\
\text { Productivity Change }\end{array}$ \\
\hline 2002 & 0.985 & 1.093 & 1.007 & 0.978 & 1.077 \\
2003 & 1.002 & 1.034 & 0.971 & 1.033 & 1.037 \\
2004 & 1.054 & 0.863 & 1.039 & 1.015 & 0.910 \\
2005 & 0.971 & 1.230 & 0.973 & 0.998 & 1.195 \\
2006 & 0.951 & 1.033 & 1.025 & 0.928 & 0.982 \\
2007 & 1.005 & 1.003 & 0.986 & 1.019 & 1.008 \\
2008 & 0.933 & 1.127 & 0.946 & 0.944 & 1.007 \\
MEAN & $\mathbf{0 . 9 7 9}$ & $\mathbf{1 . 0 4 9}$ & $\mathbf{0 . 9 9 2}$ & $\mathbf{0 . 9 8 7}$ & $\mathbf{1 . 0 2 7}$ \\
\hline
\end{tabular}

Source: Authors' Computation.

The results of Table 2 revealed that technical efficiency change mostly rose in periods during consolidation (1.013), followed by in pre-consolidation period with (0.994) and was least in the post-consolidation era with 0.950 score. Similar results were found for pure technical efficiency change and scale efficiency change. Consolidation period recorded 1.006 pure technical efficiency change and 1.007 scale efficiency change. Before consolidation, pure technical efficiency change was 0.989 and scale efficiency change equaled 1.006, whereas, post-consolidation period recorded a lower results which are 0.986 pure technical efficiency change and 0.964 scale efficiency change.

Table 2. Productivity change of the deposit money banks before, during and after consolidation and their statistical differences (2002-2008) (Note 5)

\begin{tabular}{|c|c|c|c|c|c|c|}
\hline Periods & $\begin{array}{c}\text { Technical } \\
\text { Efficiency } \\
\text { Change } \\
\end{array}$ & $\begin{array}{c}\text { Technological } \\
\text { Change }\end{array}$ & $\begin{array}{c}\text { Pure Technical } \\
\text { Efficiency } \\
\text { Change } \\
\end{array}$ & $\begin{array}{c}\text { Scale } \\
\text { Efficiency } \\
\text { Change } \\
\end{array}$ & $\begin{array}{c}\text { Total Factor } \\
\text { Productivity } \\
\text { Change }\end{array}$ & $\begin{array}{c}\text { Friedman's } \\
\text { ANOVA Mean } \\
\text { Rank } \\
\end{array}$ \\
\hline Pre & 0.994 & 1.064 & 0.989 & 1.006 & 1.057 & 2.40 \\
\hline During & 1.013 & 1.047 & 1.006 & 1.007 & 1.053 & 2.40 \\
\hline Post & 0.950 & 1.054 & 0.986 & 0.964 & 0.999 & 1.20 \\
\hline
\end{tabular}

Note. Chi-square, 4.800; Asymp., Sig. 0.091.

Source: Authors' Computation.

In addition, the banking sector had the highest technological progress during pre-consolidation period with the value of 1.064, followed by post-consolidation period with 1.054 and least during the period of consolidation with 1.047. Total factor productivity growth rose faster during pre-consolidation period with the value 1.057 and was succeeded by consolidation period with 1.053 . However, there was total factor productivity decline in the post-consolidation period with 0.999 score. Based on the Friedman's ANOVA test ranking results in the table, the productivity changes during consolidation and before consolidation periods were the same with 2.40 weights each. Post-consolidation productivity changes were ranked last with 1.20 weights.Therefore, from the foregoing one could conclude that total factor productivity changes including technical efficiency change, technological change, pure technical efficiency change and scale efficiency change were more or less statistically the same during and before consolidation in terms of significant difference, and that the productivity changes were lesser in periods after consolidation. The test statistic was 4.800 with significance value of 0.091 . This means that the differences in the productivity change weights of the banks over the three periods are significant at $10 \%$. Contrary to economic reasoning that consolidation influences productivity positively; the gain of consolidation 
in terms of productivity growth was not immediately felt possibly because of the immediate effects of restructuring. If deregulation results are compared with consolidation results in a way, findings here would deviate from that of Humphrey (1993) that found increase in bank productivity during pre-deregulation periods, a little change in productivity in post-deregulation era and a substantial fall during deregulation era. Similar productivity change found during pre-consolidation and consolidation periods in this study can be supported by the fact that there was no significant change in the quality of staff during these two periods. Rather, most banks downsized during the consolidation period.

The outcomes of Table 3 showed that the technical and pure technical efficiency changes of the domestic banks were higher than those of the foreign banks over the period 2001-2008. While domestic banks recorded technical efficiency change of 0.983 and pure technical efficiency change of 0.996 , foreign banks recorded 0.968 technical efficiency change and 0.976 pure technical efficiency change, respectively. However, foreign banks performed better in technological change, scale efficiency change and total factor productivity change. Foreign banks recorded 1.085 technological change, 0.992 scale efficiency change and 1.069 total factor productivity change as against 1.043 technological change, 0.987 scale efficiency change and 1.024 total factor productivity change obtained by domestic banks. Clearly, there was no significant difference in the productivity changes of the domestic and foreign banks. This could be substantiated by the usage of similar banking technology by both banks since the major driver of productivity was found to be technological progress.

Table 3. Productivity changes of the domestic and foreign banks

\begin{tabular}{lccccc}
\hline Banks & $\begin{array}{c}\text { Technical } \\
\text { Efficiency } \\
\text { Change }\end{array}$ & $\begin{array}{c}\text { Technological } \\
\text { Change }\end{array}$ & $\begin{array}{c}\text { Pure Technical } \\
\text { Efficiency } \\
\text { Change }\end{array}$ & $\begin{array}{c}\text { Scale Efficiency } \\
\text { Change }\end{array}$ & $\begin{array}{c}\text { Total Factor } \\
\text { Productivity } \\
\text { Change }\end{array}$ \\
\hline Domestic & 0.983 & 1.043 & 0.996 & 0.987 & 1.024 \\
Foreign & 0.968 & 1.085 & 0.976 & 0.992 & 1.069 \\
\hline
\end{tabular}

Source: Authors' Computation.

\section{Concluding Remarks}

In this paper, attempts are made to investigate consolidation- total factor productivity relationship of the deposit money banks in Nigeria over the period, 2001-2008. Both domestic and foreign banks were cross-examined. The revelation from the study that total factor productivity is prominently accounted for by technological change calls for the need for the banks to continually enhance their technologies in all centres of operation, be it local or urban settings. The foreign banks should provide market leadership in this regard.

To regulators, the policy awareness that productivity of the banks do not pick up immediately after consolidation demands that they need to intensify their oversight roles on them in post-consolidation period more than any other periods so as not to wait too long before reaping the gains of the consolidation policy. It is natural for bank workers whether skilled, semi-skilled or unskilled to exert much effort to meet targets during consolidation period. They must, however, continue to exert the same quantum of energy in operations and other functionalities as well as engage in the needed brainstorming so as to enhance results in post-consolidation era. They must also be proactive in dealing with internal rigidities arising from merger and acquisition and other consolidation activities.

\section{Acknowledgement}

We wish to thank the African Economic Research Consortium (AERC) for their research grant for this study. Any error(s) that may be found in the paper is/are entirely ours.

\section{References}

Bauer, P., Berger, A. N., \& Humphrey, D. B. (1993). Efficiency and productivity growth in US banking. In H. O. Fried, C. A. K. Lovell \& S. S. Schmidt (Eds.), The measurement of productive efficiency: Techniques and applications (pp. 386-413). Oxford University Press: United Kingdom.

Berg, S. A., Forsund, F., \& Jansen, E. (1992). Malmquist indices of productivity during the deregulation of Norwegian banking. Scandinavian Journal of Economics, 94, 211-228. http://dx.doi.org/10.2307/3440261

Casu, B., Giradone, C., \& Molyneux, P. (2004). Productivity change in European banking: A comparison of parametric and non-parametric approaches. Journal of Banking and Finance, 28, 2521-2540. 
http://dx.doi.org/10.1016/j.jbankfin.2003.10.014

Central Bank of Nigeria Statistical Bulletin. (2006). Abuja (Volume 17). CBN.

Coelli, T. J., Rao, D. S. P., O’Donnell, C. J., \& Battese, G. E. (2005). An introduction to efficiency and productivity (2nd ed.). New York, NY: Springer.

Fernandez, A. I., Gascon, F., \& Gonzalez, E. (2002). Economic efficiency and value maximization in banking firms. Paper Presented to the 7th European Workshop on Efficiency and Productivity Analysis, Oviedo, September.

Field, A. P. (2009). Discussing Statistics using SPSS (3rd ed.). London: SAGE.

Humphrey, D. B. (1993). Cost and technical change: Effects from bank deregulation. Journal of Productivity Analysis, 4, 5-34. http://dx.doi.org/10.1007/BF01073463

Lee, B. L., Worthington, A. C., \& Leong, W. H. (2008). Malmquist indices of pre and post-deregulation productivity, efficiency and technological change in the Singaporean banking sector. Economics Division, Ministry of Trade and Industry of Singapore Working/ Discussion Paper 228. Retrieved from http://core.kmi.open.ac.uk/download/pdf/6524315.pdf

Oke, D. M. (2011). Bank consolidation and scale economies trend of banks in a developing country. Journal of Economics Theory, 5(1), 15-21. Retrieved http://docsdrive.com/pdfs/medwelljournals/jeth/2011/15-21.pdf

Rao, A. (2002). Estimation of efficiency, scale and scope and productivity measures of UAE banks. Paper Presented at the European Conference of Financial Management Association International (FMAI-USA), 6 June 2002 at Copenhagen, Denmark.

Schure, P., Wagenvoort, R., \& O'Brien, D. (2004). The efficiency and the conduct of European banks: Developments after 1992. Review of Financial Economics, 13(4), 371-396. http://dx.doi.org/10.1016/j.rfe.2004.01.001

Sufian, F., \& Majid, M. A. (2007). The efficiency of merchant banks and finance companies in an emerging market: Determinants and policy Issues. Business, Finance and Economies in Emerging Economies, 2(1), 174-204. Retrieved from http://www.ccmf-uwi.org

\section{Notes}

Note 1. Deposit money banks are resident corporations and quasi-corporations which have any liabilities in the form of deposits payable on demand, transferable by cheque or otherwise usable for making payments.

Note 2. First City Monument Bank Plc and Intercontinental Bank Plc (which has merged with Access Bank) were excluded because they did not have accounting information for 2001 and 2004 respectively due to alteration in accounting year.

Note 3. The figure is obtained from calculation using our sample data and Central Bank of Nigeria data.

Note 4. The banks sampled include Union Bank of Nigeria Plc, First Bank of Nigeria Plc, United Bank for Africa Plc, Zenith Bank Plc, Access Bank Plc, Wema Bank Plc, Guaranty Trust Bank Plc, Oceanic Bank International Limited (has merged with Ecobank Nigeria Plc), Equatorial Trust Bank Limited (has merged with some banks to form Sterling Bank Plc), Afribank Plc, Diamond Bank Limited, Fidelity Bank Plc, Ecobank Nigeria Plc, Standard Chartered Bank Limited, and Citibank Nigeria Limited (formerly Known as Nigeria International Bank Limited). The last three are foreign banks while others are domestic banks. A bank is described as foreign if at least 50 per cent of its shares are owned by foreigners whether individuals or institutions, otherwise it is a domestic bank.

Note 5. Pre-consolidation period is 2001-2003; consolidation era is 2004-2005 and post consolidation period covers 2006-2008. The means of the Total Factor Productivity indices are in geometric forms. 


\section{Appendix A.}

$$
\begin{array}{r}
\left\{\mathrm{d}_{\mathrm{o}}^{\mathrm{t}}\left(\mathrm{q}_{\mathrm{t}}, \mathrm{x}_{\mathrm{t}}\right)\right\}^{-1}=\operatorname{Max}_{\varnothing, \lambda} \varnothing, \\
\text { Subject to }-\varnothing \mathrm{q}_{\mathrm{it}}+\mathrm{Q}_{\mathrm{t}} \lambda \geq 0, \\
\mathrm{x}_{\mathrm{it}}-\mathrm{X}_{\mathrm{t}} \lambda \geq 0 \\
\lambda \geq 0, \\
\left\{\mathrm{~d}_{\mathrm{o}}^{\mathrm{s}}\left(\mathrm{q}_{\mathrm{s}}, \mathrm{x}_{\mathrm{s}}\right)\right\}^{-1}=\operatorname{Max}_{\varnothing, \lambda} \varnothing, \\
\text { Subject to }-\varnothing \mathrm{q}_{\mathrm{is}}+\mathrm{Q}_{\mathrm{s}} \lambda \geq 0, \\
\mathrm{x}_{\mathrm{is}}-\mathrm{X}_{\mathrm{s}} \lambda \geq 0, \\
\lambda \geq 0, \\
\left\{\mathrm{~d}_{\mathrm{o}}{ }^{\mathrm{t}}\left(\mathrm{q}_{\mathrm{s}}, \mathrm{x}_{\mathrm{t}}\right)\right\}^{-1}=\operatorname{Max}_{\varnothing, \lambda} \varnothing,
\end{array}
$$

Subject to $-\emptyset_{\mathrm{q}_{\text {is }}}+\mathrm{Q}_{\mathrm{t}} \lambda \geq 0$,

$$
\mathrm{x}_{\mathrm{is}}-\mathrm{X}_{\mathrm{t}} \lambda \geq 0
$$$$
\lambda \geq 0 \text {, }
$$

$$
\left\{\mathrm{d}_{\mathrm{o}}^{\mathrm{s}}\left(\mathrm{q}_{\mathrm{t}}, \mathrm{x}_{\mathrm{t}}\right)\right\}^{-1}=\operatorname{Max}_{\varnothing, \lambda} \varnothing,
$$

Subject to $-\varnothing_{q_{i t}}+Q_{s} \lambda \geq 0$,

$$
\mathrm{X}_{\mathrm{it}}-\mathrm{X}_{\mathrm{s}} \lambda \geq 0 \text {, }
$$$$
\lambda \geq 0,
$$$$
\left\{\mathrm{d}_{\mathrm{o}}^{\mathrm{t}}\left(\mathrm{q}_{\mathrm{t}}, \mathrm{x}_{\mathrm{t}}\right)\right\}^{-2}=\operatorname{Max}_{\varnothing, \lambda} \varnothing,
$$

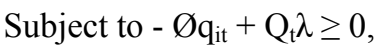$$
\mathrm{x}_{\mathrm{it}}-\mathrm{X}_{\mathrm{t}} \lambda \geq 0 \text {, }
$$$$
\text { I1 } \lambda=1
$$$$
\lambda \geq 0 \text {, }
$$

and

$$
\left\{\mathrm{d}_{\mathrm{o}}{ }^{\mathrm{s}}\left(\mathrm{q}_{\mathrm{s}}, \mathrm{x}_{\mathrm{s}}\right)\right\}^{-2}=\operatorname{Max}_{\varnothing, \lambda} \varnothing,
$$

Subject to $-\varnothing \mathrm{q}_{\text {is }}+\mathrm{Q}_{\mathrm{s}} \lambda \geq 0$,

$$
\begin{aligned}
& \mathrm{x}_{\mathrm{is}}-\mathrm{X}_{\mathrm{s}} \lambda \geq 0, \\
& \text { I1 } \lambda=1 \\
& \lambda \geq 0,
\end{aligned}
$$

Where $\mathrm{d}_{\mathrm{o}}$ represents distance of each data point relative to a common technology; ' $t$ ' stands for current period; ' $\mathrm{s}$ ' is base period; ' $\mathrm{x}$ ' is input; ' $\mathrm{q}$ ' is output; ' $\varnothing$ ' is a scalar and $\lambda$ is a $I \times 1$ vector of constants. The value of $\varnothing$ obtained is the productivity/ efficiency score. Movement terminates at the common or reference technology irrespective of whether $\mathbf{s}$ is the base period. The letter $\mathbf{d}_{\mathbf{o}}$ shows the reference technology. For instance, the notation $\mathrm{do}^{\mathrm{s}}\left(\mathrm{q}_{\mathrm{t}} \mathrm{x}_{\mathrm{t}}\right)$ represents the distance from the period $\mathrm{t}$ observation to the period $\mathrm{s}$ technology

\section{Copyrights}

Copyright for this article is retained by the author(s), with first publication rights granted to the journal.

This is an open-access article distributed under the te rms and conditions of the Creative Commons Attribution license (http://creativecommons.org/licenses/by/3.0/). 